International Journal of Life Sciences
Available online at www.Sciencescholar.us
Vol. 5 No. 3, December 2021, pages: 148-155
e-ISSN: 2550-6986, p-ISSN: 2550-6994
https://doi.org/10.53730/ijls.v5n3.1599

\title{
Business Strategy of Laying Hens towards New Normal Era
}

Ni Kadek Mita Sumadi Astrini a ${ }^{2}$, Budi Rahayu Tanama Putri b ${ }^{\text {b }}$, James Hellyward c
Manuscript submitted: 27 August 2021, Manuscript revised:18 September 2021, Accepted for publication: 09 October 2021

International Journal of Life Sciences (C) 2021. This is an open access article under the CC BY-NC-ND license (https://creativecommons.org/licenses/by-nc-nd/4.0/).

\section{Contents}

Abstract



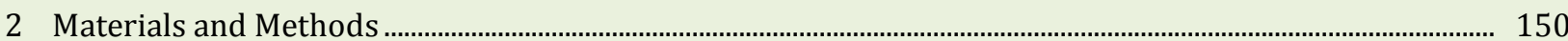

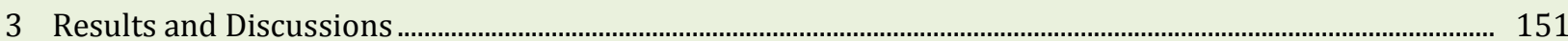

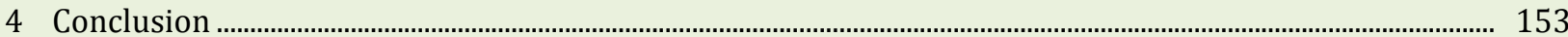

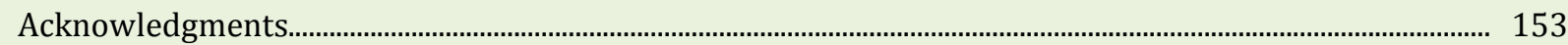

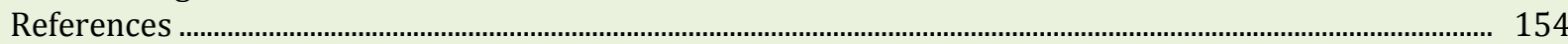

a Udayana University, Denpasar, Indonesia

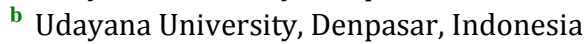

c Andalas University, Padang, Indonesia 


\section{Introduction}

The livestock sector has a strategic role in meeting the needs of people's lives. The livestock industry in the poultry sub-sector provides animal protein to fulfill people's nutritional needs. The protein contained in animal food has an important function in people's daily lives because it contains amino acids needed for human growth and intelligence (Widyantara, 2017). Based on this matter, the community cooperates with the government to aggressively develop livestock businesses. One of the farms developed is the livestock of laying hens (Ardhiana et al., 2017).

In the last few decades, there has been a high increase in requisitions for livestock products, especially chicken eggs, in Bali Province. This is also supported by data on an increase in the population of laying hens and egg production which is quite significant, in 2015 the number of broilers in Bali was 80,161,347 broilers/year, then in 2016 it became 90,059,264 broilers/year, in 2017 again increased to 100,572,360 broilers/year, in 2018 it became 101,532,190 broilers/year, and lastly, in 2019 it was 117,624,973 broilers/year. The average increase in the number of broilers is 7-9\% every year (Central Bureau of Statistics, 2019).

The increasing population of broilers in Bali is linear with the increase in egg production of broilers. In 2015 the production of broiler eggs in the Bali Province was 40,987 tons/year, this number increased to 49,004 tons/year in 2016, increased again in 2017 to 54,210 tons/year, in 2018 it was 59,100 tons/year, and lastly in 2019 the total production of broiler eggs was 65,899 tons/year. The data shows an increase in the number of broiler egg production with an average increase of $6.55 \%$ annually (Central Bureau of Statistics, 2019). It is proven by the average price of broiler eggs in 2019 which is 22,085/kg (Central Bureau of Statistics, 2020).

The high increase of requisitions for broiler eggs was caused by several things, namely an increase in population, an increase in people's income, an improvement in education levels, nutritional awareness, urbanization, and the flow of globalization which led to changes in lifestyle and consumption habits (Hasman, 2019). The requisitions for eggs in the Bali Province are not only caused by these factors but also influenced by the number of tourists who come to Bali. As a tourism area, the growth of broiler egg production in Bali Province from 2015 - 2019 has an average of 6.5\% annually (Central Bureau of Statistics, 2019). This value is above the national average percentage of $2.19 \%$ in the same year, this is due to requisitions from hotels and restaurants to fulfill the tourist consumption needs.

At the end of 2019, the world was shocked by the emergence of a new virus that attacks the respiratory system, known as Corona Virus Disease 2019 (COVID-19). The spread of the COVID-19 Virus in Indonesia has been going on so fast since March 2020. The occurrence of the COVID-19 pandemic has an impact on all sectors, including the laying hen's livestock business (Ritter \& Gemünden, 2004). The people, including the laying hen's livestock business in Bali Province, must be able to coexist with the COVID-19 virus. Living side by side with the COVID-19 virus is known as the new normal era (Uryu et al., 2021).

The new normal era is a scenario term to accelerate the handling of COVID-19 in health and socioeconomic aspects. The new normal era has also changed all people's habits, one of which is in the selling and purchasing of a product, including how to sell chicken eggs (Widyantara \& Sukaatmadja, 2019). In the new normal era, people including laying hens in the Bali Province are required to be flexible because the new normal era contains many very fast changes (Busetti et al., 2021). These changes include changes in the market, changes in consumer behavior.

The biggest impact occurred in the new normal era, such as on the requisitions for broiler eggs. The requisitions for broiler eggs in Bali in 2020 in the range of March-August 2020 have decreased quite significantly. In April there was a decrease in requisitions for broiler eggs by $56 \%$ from March. In May it fell again by $60 \%$ from April. In June and July, requisitions gradually increase. In June the demand increased by $10 \%$ and in July it decreased by 18\% (Directorate General of Livestock, 2020).

The decrease in requisitions for broiler eggs was caused by a drastic decrease in tourist arrivals to Bali. Based on data from the Central Bureau of Statistics (2020), foreign tourists who came directly to Bali Province in September 2020 were recorded at 32 visits. The number of foreign tourists who come through I Gusti

Astrini, N. K. M. S., Putri, B. R. T., \& Hellyward, J. (2021). Business strategy of laying hens towards new normal era. International Journal of Life Sciences, 5(3), 148-155. https://doi.org/10.53730/ijls.v5n3.1599 
Ngurah Rai airport is 10 visits and the seaport is 22 visits. The number of foreign tourists to Bali Province in September 2020 decreased by $11.11 \%$ compared with the August 2020 record (month to month). When compared to September 2019 (year to year), the number of foreign tourists to Bali Province was recorded to have fallen by almost 99\%. Meanwhile, domestic tourists visiting Bali Province in the same month decreased by $92.45 \%$. Hotels and restaurants are one aspect of the market for broiler eggs, in this case, eggs are used as the basic ingredients for dishes for visiting tourists. Restrictions on people's activities are also the cause of the decline in demand for broiler eggs. Restrictions on people's activities lead to reduced community activities outside the home which also results in reduced sales of egg-based foods.

The decline in the requisitions for boiler chicken eggs greatly affected the availability of boiler chicken eggs in the Bali Province, because the decline in the requisitions for boiler chicken eggs resulted in the excess stock of boilers chicken eggs in the Bali Province. In addition, the shelf life of boilers chicken eggs is not long enough and results in a decrease in the price of purebred chicken eggs to avoid the excess stock (Xu et al., 2019; Srinivasan et al., 2013). Based on this, marketing is a major problem in the new normal era.

Based on this background, it is necessary to study the strategy of laying hens in the new normal era in Bali Province. The results of this study will be able to provide information to farmers regarding business strategies to maintain the income of laying hens in the province of Bali in the new normal era (Ghosh, 2016).

\section{Materials and Methods}

This research was conducted in 8 districts in the Bali Province, namely Karangsem, Klungkung, Bangli, Gianyar, Badung, Tabanan, Jembrana, and Buleleng. The research was conducted from January - March 2021. The research location was determined by the purposive sampling method. This research is survey research that uses a mixed-method between quantitative and qualitative which aims to obtain clear and complete data from broiler egg entrepreneurs in Bali Province in the new normal era. Quantitative data is data expressed in the form of numbers, while qualitative data emphasizes aspects of in-depth understanding of a research problem (Moleong, 2007).

Internal and external data were analyzed as key factors in the Bali Province chicken egg business in the new normal era, and the data obtained were analyzed using Internal Factor Evaluation (IFE), External Factor Evaluation (EFE), Internal-External (IE), Strength-Weaknesses-Opportunities-Threats (SWOT), and Quantitative Strategic Planning Matrix (QSPM) (Van Der Klein et al., 2015; Jackson et al., 2003). The IFE matrix is a strategy formulation that summarizes and evaluates weaknesses and in the various functional aspect of the business, while the EFE matrix is a strategy formulation that summarizes and evaluates economic, social, cultural, demographic, environmental, political, government, legal, technology, and competitive information (David, 2002).

The environmental conditions of laying hens business in the Bali Province are determined based on the analysis of internal factors and analysis of external factors, to obtain the strengths, weaknesses, opportunities, and threats in the development of laying hens in the Bali Province. Each factor is weighted and ranked using the Paired Comparison method. According to David (2002), ratings were analyzed based on the importance of each factor, on a scale of 1 (low/poor), 2 (average), 3 (high/above average), 4 (very high) (Kinnear \& Tylor, 1996), with the following formula:

$$
\propto_{i}=\frac{X_{i}}{\sum_{i=1}^{n} X_{i}}
$$

\footnotetext{
Information:

$\alpha_{\mathrm{i}} \quad=$ Weight of variable to $\mathrm{i}$

$\mathrm{X}_{\mathrm{i}} \quad=$ Value of variable to 1

$\mathrm{i} \quad=1,2,3, \ldots, \mathrm{n}$

$\mathrm{n} \quad=$ Number of factors
} 
SWOT analysis is an evaluation of the company's overall strengths, weaknesses, opportunities, and threats. SWOT analysis is a way to observe the internal and external marketing environment (Kotler \& Keller, 2017; Chang \& Huang, 2006). SWOT analysis is the systematic identification of various factors to formulate a company's strategy. This analysis is based on the logic that can maximize strengths and opportunities, but at the same time minimize weaknesses and threats (Rangkuti, 1998). comparing internal and external factors, to obtain alternative strategies that maximize Strengths and Opportunities, and minimize Weaknesses and Threats (Putri et al., 2017).

QSPM analysis is a tool recommended to strategists to evaluate alternative strategic options objectively based on the previously identified internal-external key success factors. So conceptually, the purpose of QSPM is to determine the relative attractiveness of the various strategies that have been chosen and to determine which strategy is considered the best to implement (Putri, 2014). QSPM analysis is used to evaluate alternative strategies based on the attractiveness score of each strategy. The attractiveness score (AS) is determined by examining internal and external factors, as well as the role of each factor in the strategy selection process. The AS scores are: $1=$ not attractive, $2=$ somewhat attractive, $3=$ attractive, $4=$ very attractive (Putri \& Suparta, 2018).

\section{Results and Discussions}

Based on the results of the analysis of internal factors that exist in the laying hen's livestock business in Bali Province, obtained 5 strength factors and 4 weakness factors. The strength and weakness factors are then given weight and rating by expert respondents. The results of the weighting and rating of internal strategy factors can be seen in Table 1.

Table 1

Determination of internal strategy factor scores

\begin{tabular}{|c|c|c|c|c|}
\hline No & Determinants Factor & Weight & Rating & Score \\
\hline \multicolumn{5}{|c|}{ Strength } \\
\hline 1 & Breeder have used appropriate technology & 0,18 & 4 & 0,72 \\
\hline 2 & Have good maintenance management & 0,15 & 4 & 0,59 \\
\hline 3 & All farmers are in productive age & 0,07 & 3 & 0,20 \\
\hline 4 & $\begin{array}{l}\text { On average, laying hens businesses have facilities for delivering broiler } \\
\text { eggs to buyers }\end{array}$ & 0,18 & 4 & 0,72 \\
\hline 5 & $\begin{array}{l}\text { Farmers on average have mobile phones and social media accounts } \\
\text { Sub Total Strength }\end{array}$ & 0,18 & 4 & $\begin{array}{l}0,72 \\
2,95\end{array}$ \\
\hline \multicolumn{5}{|c|}{ Weakness } \\
\hline 1 & Most of the farmers have not recorded business finances & 0,11 & 3 & 0,33 \\
\hline 2 & $\begin{array}{l}\text { The average farmer has no interest in the processing of laying hens } \\
\text { livestock }\end{array}$ & 0,07 & 3 & 0,20 \\
\hline 3 & There is still a lack of understanding of farmers about e-commerce & 0.04 & 3 & 0,11 \\
\hline \multirow[t]{3}{*}{4} & $\begin{array}{l}\text { Farmers have not made maximum use of social media as a place to do } \\
\text { marketing }\end{array}$ & 0,04 & 3 & 0,11 \\
\hline & Sub Total Weakness & & & 0,74 \\
\hline & Total & & & 3,69 \\
\hline
\end{tabular}

The results of data processing obtained from respondents gave a sub-total value of the strength of 2.95 , a subtotal value of weakness of 0.74 , and a total value of internal factors was 3.69 (Table 1). This total value shows that marketing has quite good strength factors compared to its weakness factors.

Based on the results of the analysis of external factors that exist outside the laying hen's livestock business in Bali Province, there are 3 opportunity factors and 2 threat factors. The opportunity and threat factors are

Astrini, N. K. M. S., Putri, B. R. T., \& Hellyward, J. (2021). Business strategy of laying hens towards new normal era. International Journal of Life Sciences, 5(3), 148-155. https://doi.org/10.53730/ijls.v5n3.1599 
then given weights and ratings by expert respondents. The results of the weighting and rating of internal strategy factors can be seen in Table 2 .

Table 2

Determining the external strategy factor score

\begin{tabular}{|c|c|c|c|c|}
\hline No & Determinants Factor & Weight & Rating & Score \\
\hline \multicolumn{5}{|c|}{ Opportunity } \\
\hline 1 & In the new normal era, oriented to a healthy lifestyle & 0,18 & 4 & 0,78 \\
\hline 2 & Almost all people activities have shifted from offline to online & 0,18 & 4 & 0,62 \\
\hline 3 & $\begin{array}{l}\text { On average, all regions in Bali Province already have an internet } \\
\text { network. }\end{array}$ & 0,15 & 4 & 0,62 \\
\hline & Sub Total Opportunity & & & 2,02 \\
\hline \multicolumn{5}{|c|}{ Threat } \\
\hline 1 & Factory livestock feed prices continue to increase & 0,24 & 3 & 0,71 \\
\hline \multirow[t]{3}{*}{2} & $\begin{array}{l}\text { In the new normal era, people carry out activities with minimal } \\
\text { physical contact }\end{array}$ & 0,38 & 3 & 1,61 \\
\hline & Sub Total Threat & & & 0,71 \\
\hline & Total & & & 2,73 \\
\hline
\end{tabular}

Based on the results of data processing, the sub-total value of the opportunity factor was 2.02 and the subtotal threat was 0.71 (Table 2). The total EFE value of 2.73 (Table 2) indicates that laying hens businesses in Bali Province generally have a quite good ability to respond to existing opportunities. However, farmers still have a big threat where the price of factory livestock feed continues to increase, as well as the availability of fluctuating local raw materials, judging from the rating on the threat factor ranging from number 3 . The ability of farmers is still low to avoid threats Availability of fluctuating local raw materials. Even though farmers are currently able to overcome the existing threats, this is not yet strong enough to overcome the existing threats.

The IE Matrix shows that laying hens business in Bali Province is in the fourth cell (Figure 1) with an EFI value of 3.69 (Table 1) and an EFE value of 2.73 (Table 2). into the first group, namely the growth and build strategy. With alternative strategies: intensive strategy (market penetration, market development, product development) or integrative (backward, forward, horizontal integration)

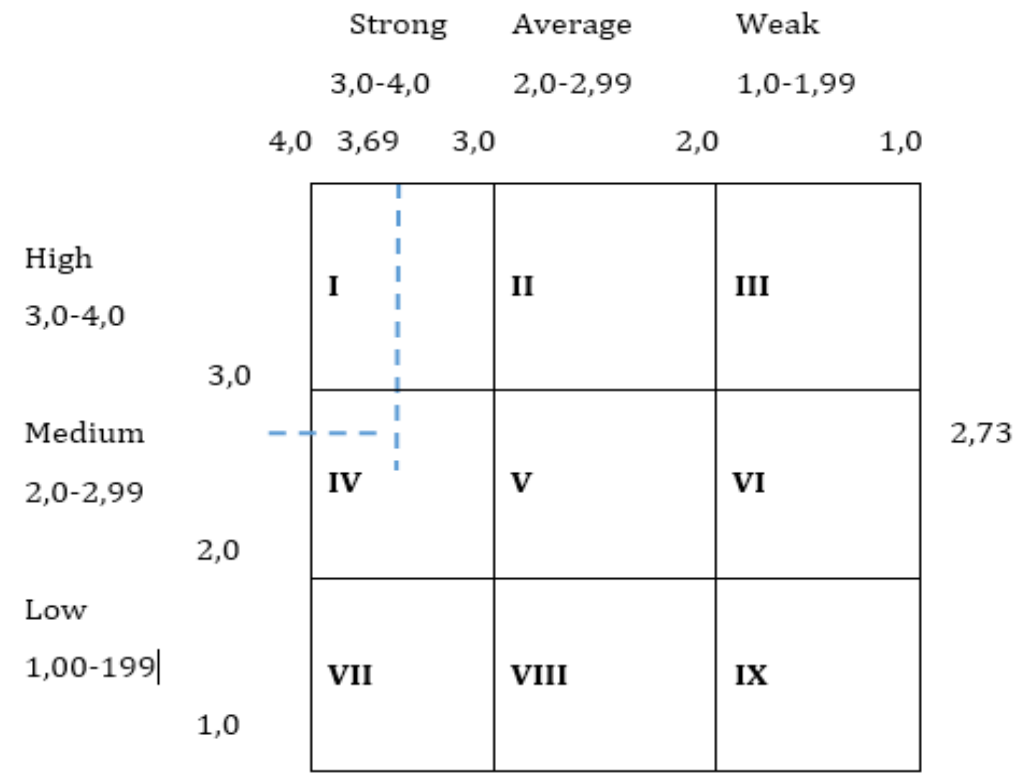

Figure 1. The IE Matrix shows laying hens business in the New Normal Era in Bali Province 


\section{Strategy recommendations}

The formulation strategy is carried out by combining various factors that have been identified and grouped. The results of this formulation strategy are grouped into four group formulation strategies consisting of opportunities-power (SO), threat-power (ST), opportunities-weak (WO), and weaknesses (WT) strategies (Görener et al., 2012).

The SWOT analysis of the results of the strategy formulation needs to be implemented in the policy formulation business strategy for laying hens in the Bali Province. The recommended alternative strategies are: 1) implementing digital marketing, 2) implementing SIAP (Laying Chicken Information System), 3) counseling and mentoring on the use of e-commerce, 4) collaborating with platforms that handle the livestock sector, 5) training and mentoring for the people regarding egg-based business opportunities, 6) establishing industrial clusters for laying hens, 7) developing livestock cooperatives (Chang et al., 2003).

Based on the results of the QSPM analysis that has been carried out, counseling and assistance on the use of e-commerce with a TAS value of 4.58 is a priority strategy where this strategy must be carried out first. Collaborating with a platform that handles the livestock sector is the second strategy with a TAS value of 3.49. The third strategy, which is implementing digital marketing, this strategy has a TAS value of 2.92. The fourth strategy is training and mentoring the community regarding egg-based business opportunities with a TAS value of 2.84. Establishing an industrial cluster of laying hens is the fifth strategy with a TAS value of 2.66. The sixth strategy is the development of cooperatives with a TAS value of 2.55. The application of SIAP (Laying Chicken Information System) is the final strategy as well as the main strategy with a bag value of 1.74 .

\section{Conclusion}

1) Based on the analysis that has been carried out in this study, it can be concluded that the laying hens business in Bali Province in the New Normal Era in the IE matrix is located in quadrant IV with an internal score of 3.69 and an external factor score of 2.73 .

2) Seven alternative strategies are recommended for laying hens in the province of Bali, such as; 1) implementing digital marketing, 2) implementing SIAP (Laying Chicken Information System), 3) counseling and mentoring on the use of e-commerce, 4) collaborating with platforms that handle the livestock sector, 5) training and mentoring the community regarding business opportunities based on eggs, 6) establishing industrial clusters for laying hens, 7) developing livestock cooperatives.

Acknowledgments

We are grateful to two anonymous reviewers for their valuable comments on the earlier version of this paper.

Astrini, N. K. M. S., Putri, B. R. T., \& Hellyward, J. (2021). Business strategy of laying hens towards new normal era. International Journal of Life Sciences, 5(3), 148-155. https://doi.org/10.53730/ijls.v5n3.1599 


\section{References}

Ardhiana, N. (2017). Program Penyediaan Air Minum dan Sanitasi Berbasis Masyarakat (Pamsimas) dalam menyejahterahkan masyarakat di Dusun Jurangjer0, Desa Jatigreges, Kec. Pace, Kab. Nganjuk (Doctoral dissertation, Universitas Negeri Malang).

Badan Pusat Statistik. (2020). Jumlah Produksi Telur Ayam Ras tiap Kabupaten di Provinsi Bali. Badan Pusat Statistik, Bali

Badan Pusat Statistika. (2019). Laporan Konsumsi Protein Penduduk Tahun 2019. Badan Pusat Statistika, Bali

Busetti, F., Neri, S., Notarpietro, A., \& Pisani, M. (2021). Monetary policy strategies in the New Normal: a model-based analysis for the euro area.Journal of Macroeconomics, 103366. https://doi.org/10.1016/j.jmacro.2021.103366

Chang, H. H., \& Huang, W. C. (2006). Application of a quantification SWOT analytical method. Mathematical and computer modelling, 43(1-2), 158-169. https://doi.org/10.1016/j.mcm.2005.08.016

Chang, S. C., Yang, C. L., Cheng, H. C., \& Sheu, C. (2003). Manufacturing flexibility and business strategy: an empirical study of small and medium sized firms. International Journal of Production Economics, 83(1), 1326. https://doi.org/10.1016/S0925-5273(02)00263-3

David, F. R. (2002). Manajemen strategis: konsep.

Direktorat Jendral Peternakan dan Kesehatan Hewan. (2020). Statistik Permintaan Telur Ayam Ras. Jakarta: Direktorat Jendral Peternakan dan Kesehatan Hewan.

Ghosh, C. (2016). The evaluation of new marketing strategy of selected home appliances. International research journal of management, IT and social sciences, 3(11), 33-38.

Görener, A., Toker, K., \& Ulucay, K. (2012). Application of combined SWOT and AHP: a case study for a manufacturing firm. Procedia-social and behavioral sciences, 58, 1525-1534. https://doi.org/10.1016/j.sbspro.2012.09.1139

Hasman, R. (2019). Permintaan Dan Penawaran Telur Ayam Ras Di Kabupaten Donggala (Doctoral dissertation, Universitas Tadulako).

Jackson, S. E., Joshi, A., \& Erhardt, N. L. (2003). Recent research on team and organizational diversity: SWOT analysis and implications. Journal of management,29(6), 801-830. https://doi.org/10.1016/S01492063(03)00080-1

Kinnear, T. C., \& Taylor, J. R. (1996). Marketing research: an applied approach. McGraw-Hill.

Kotler, P., \& Keller, K. L. (2017). Marketing Management. $13^{\text {th }}$ Ed. Prentice Hall: Person Education, Inc. Jakarta.

Moleong, L. J. (2007). Metodologi Penelitian Kualitatif, Bandung: PT Remaja Rosdakarya Offset.

Putri, B. R. T. (2014). Strategi manajemen usaha dan sistem agribisnis perbibitan sapi Bali untuk meningkatkan pendapatan peternak. Disertasi Program Pascasarjana Universitas Udayana, Bali.

Putri, B. R. T., \& Suparta, N. (2018). A Development Strategy of Native Pig Farming in Nusa Penida SubDistrict, Bali Province. Journal of Biological and Chemical Research 35(1), 257-261.

Putri, B. R. T., Bidura, I. G. N. G., Partama, I. B. G., Hellyward, J., \& Inggriati, N. W. T. (2017). Strategy of Business Development Based on Potential Area of Livestock in Gianyar Regency. In International Seminar on Tropical Animal Production (ISTAP) (pp. 515-521).

Rangkuti, F. (1998). Analisis SWOT teknik membedah kasus bisnis. Gramedia Pustaka Utama.

Ritter, T., \& Gemünden, H. G. (2004). The impact of a company's business strategy on its technological competence, network competence and innovation success. Journal of business research, 57(5), 548-556. https://doi.org/10.1016/S0148-2963(02)00320-X

Srinivasan, P., Balasubramaniam, G. A., Murthy, T. R. G. K., \& Balachandran, P. (2013). Bacteriological and pathological studies of egg peritonitis in commercial layer chicken in Namakkal area. Asian Pacific journal of tropical biomedicine, 3(12), 988-994. https://doi.org/10.1016/S2221-1691(13)60191-4

Uryu, S., Tanoue, Y., Nomura, S., Matsuura, K., Makiyama, K., Kawashima, T., ... \& Hashizume, M. (2021). Trends in emergency transportation due to heat illness under the new normal lifestyle in the COVID-19 era, in Japan and 47 prefectures.Science of the Total Environment, 768, 144723. https://doi.org/10.1016/j.scitotenv.2020.144723

Van Der Klein, S. A. S., Berghof, T. V. L., Arts, J. A. J., Parmentier, H. K., Van Der Poel, J. J., \& Bovenhuis, A. H. (2015). Genetic relations between natural antibodies binding keyhole limpet hemocyanin and production traits in a purebred layer chicken line. Poultry Science, 94(5), 875-882. https://doi.org/10.3382/ps/pev052 
Widyantara, I. N. P., \& Ardani, I. G. A. K. S. (2017). Analisis Strategi Pemasaran Telur Ayam (Studi Kasus Di Desa Pesedahan dan Desa Bugbug, Kabupaten Karangasem) (Doctoral dissertation, Udayana University).

Widyantara, I. N. P., \& Sukaatmadja, I. P. G. (2019). Formulation of chicken egg marketing strategy. International research journal of management, IT and social sciences, 6(5), 285-302.

Xu, Z. Y., Yu, Y., Liu, Y., Ou, C. B., Zhang, Y. H., Liu, T. Y., ... \& Ma, J. Y. (2019). Differential expression of proinflammatory and anti-inflammatory genes of layer chicken bursa after experimental infection with infectious bursal disease virus. Poultry science, 98(11), 5307-5314. https://doi.org/10.3382/ps/pez312

\section{Biography of Authors}

\begin{tabular}{|l|l|}
\hline Ni Kadek Mita Sumadi Astrini is a graduate student of the Master Program at \\
Udayana University majoring in Animal Science. The woman who was born in \\
Karangasem Bali, May 5, 1997, is interested in the socio-economic science of \\
animal husbandry, Faculty of Animal Husbandry, Udayana University, Denpasar \\
City, Bali, Indonesia. Phone +6281337026855. Jalan P.B Sudirman, Bali Indonesia. \\
Email: mitasumadi88@gmail.com
\end{tabular} \mid $\begin{aligned} & \text { Dr. Ir. Budi Rahayu Tanama Putri,S.Pt.MM.,IPM.,ASEAN.Eng was born in } \\
& \text { Karangasem on 26th December 1978. Career Lecturers began in 2005, as a } \\
& \text { lecturer in socio-economic farming at the Faculty of Animal Husbandry, Udayana } \\
& \text { University. Currently, the author is still active as teaching staff in the S1, S2, S3 } \\
& \text { Faculty of Animal Husbandry Study Programs, as well as the Professional Engineer } \\
& \text { Program at Udayana University. The author is active in research and service } \\
& \text { activities and publishes the results of his activities in various scientific meetings } \\
& \text { and national and international journals. Hp.WA: 08123611755 } \\
& \text { Email: tanamaputri@unud.ac.id }\end{aligned}$

Astrini, N. K. M. S., Putri, B. R. T., \& Hellyward, J. (2021). Business strategy of laying hens towards new normal era. International Journal of Life Sciences, 5(3), 148-155. https://doi.org/10.53730/ijls.v5n3.1599 